\title{
Hospitality and Tourism Education and Making of Entreprenuers: A Review
}

\author{
Polycarp A. Igbojekwe*, Omelebele U. Anuñobi \\ Gregory University, Uturu, Abia State, Nigeria
}

*Corresponding Author: Prof. Polycarp A. Igbojekwe, Department of Hospitality Management and Tourism, College of Agriculture, Gregory University, Uturu, Abia State Nigeria

\begin{abstract}
With the inclusion of entrepreneurial education in tourism as an academic discipline in the universities, tourism education has undergone some transformations. In this review, the authors attempted to contribute to an ongoing debate as to whether hospitality and tourism education offered by universities can effectively produce entrepreneurs in these sectors of the economy. The review defined and explained entrepreneurship and who the entrepreneur is. The work examined the link between tourism entrepreneurial education and entrepreneurship interest in students and opposing views were discovered in the literature. The majority view is that there is positive relationship between entrepreneurial education and entrepreneurship interest. There are conceptual and theoretical grounds and substantial empirical evidence supporting the positive relationship between entrepreneurial education offered by universities and colleges and entrepreneurship interest. The role of higher institutions in inculcating entrepreneurship spirit in students and the structure of the academic work are proposed.
\end{abstract}

Keywords: Entrepreneur, entrepreneurial competences, entrepreneurship spirit, tourism education.

\section{OVERVIEW}

\subsection{Hospitality and Tourism Industry}

Tourism has been described as both an economic and social phenomenon having been regarded as a driving force, constituting a major source of income for socio-economic development for many countries of the world. Tourism is a growth industry, growing in the face of economic recession and even faster than the global economy; it is a sustainable source of jobs and driver of growth for each region of the world. Travel \&Tourism industry grows faster than the global economy and contributes about $10 \%$ of global GDP and $6 \%$ of the world's total exports (United Nations World Tourism Organization [UNWTO] (2015).

Hospitality and tourism are interrelated and interdependent; in other words, none can operate successfully in the absence of the other. Both hospitality and tourism are a multi-disciplinary phenomenon, thus, they are defined from different perspectives. While hospitality sector provides mainly accommodation, food and drinks to tourists, tourism sector supplies recreation and entertainment.

Tourism is defined as the set of relationships and phenomena resulting from the voluntary movement and stay of people (tourists) out of their normal place of residence as long as the movement does not lead to permanent residence and are unrelated to any gainful employment (Hunziker and Krapf, 1941) in Wikipedia.org (2020), "Temporary movement of people to destinations outside their normal work and subsistence, activities undertaken during their stay in those destinations and the facilities created to meet their needs" (Mathieson \& Wall, 2006). There are other definitions by UNWTO (2010), Macintosh and Goeldner (1986), and Jafari (2000). The common denominators in their definitions are that tourism is for pleasure (recreation) and temporary movement. The UNWTO added the trip must exceed one consecutive year for business and other purposes.

Tourism is noted to be one of the most rapidly growing industries and has becomean important economic activity in most countries of the world. (Meyer \& Meyer, 2015; Solvoll, Alsos, \&Bulanova, 2015). Also, Solvoll, et al. (2015), Ntshangase and Ezeuduji (2019) posit that tourism as an industry is 
highly competitive and dynamic. Therefore, effective entrepreneurs are needed to sustain its growth and secure it.

\subsection{Tourism Education}

Considering the current needs of the industry, Suharti (2012) in Lestari, Widyastutiand Festtivalia (2018) suggest that a university should be one of the important forces driving entrepreneurship growth. Therefore, it should implement entrepreneurial education, noting that innovation in entrepreneurially oriented teaching approach in education enables students to cultivate the skills needed to gain practical experience.

Haywood and Maki (1992) in Arranz, Ubierna, Arroyabe and Perz (2017) and Koh (1995)observed that the tourism industry needs practical and general capabilities such as computer skills, human resource management, managerial accounting and service quality management.Koh (1995); Airey and Johnson (1999), and $\mathrm{Li}$ (2008) have proposed the combination of vocational modules (hotel and restaurant operations, principles of tourism development, travel vocational modules (hotel and restaurant operations, principles of tourism development, travel and tourism industry and others) with business and entrepreneurship modules (marketing, accounting, entrepreneurship and innovation and so on) and skill-developing modules (such as written communication skills, interpersonal relation skills and more) in the tourism curriculum. However, as noted by Echtner, (1995); Tribe, (1997; Li, (2008) little research has been done on the effectiveness of these activities, and there are doubts as to the effectiveness of this training for developing entrepreneurial vocation in tourism students.

Tourism industry is one of the few sectors with industry specific training needs due to its unique features in its operations (see for example the UK case of Busby and Huang (2012) and Fidgeon (2011)). Inclusion of tourism education into the universities' programmes as an academic discipline, transformed tourism education. The degree courses have also undergone a significant and remarkable improvement at both the graduate and postgraduate levels. Another development worthy of note is the launch of doctoral programmes in this important sector (Arranz et al., 2019).

Education in hospitality and tourism sectors is not limited to universities in the UK and developed countries; some colleges and universities in Nigeria have delved into it. Some universities (Imo State University, University of Port Harcourt, Gregory University, Uturu, Michael Okpara University of Agriculture, Umudike etc.) are playing prominent role in preparing students in gaining professional and practical skills required for successful tourism business. In Nigeria, education in hospitality and tourism is virtually new at the university level; it started in the early 1990s and has passed through challenges and transformations (Ugo-Okoro, Igbojekwe\& Ogbonna, 2011). Two of the main factors that contributed to its problems as identified by these authors were, lack of collaboration between the industry and academic institutions particularly in producing curriculum, and inability of the industry to sponsor training and researches.

As tourism plays an important role in the economy, the appropriateness of tourism education in relation to employment needs to be explored. Tourism being a multidisciplinary field and characterized by a large number of micro, small and medium-sized businesses (Thomas, 2000; Ayres, 2006), the industry needs well trained entrepreneurs capable of sustaining the growth in the industry.

Tourism education is closely related to employment and career opportunities in the industry. Riley et al. (2002) see tourism education like any other form of vocationally orientated education where there should be a balance among its three imperatives: the need to promote individual development, the need to advance knowledge and skill, and the need to be practical and relevant to the industry.

Over the years, tourism industry has witnessed challenges; with the changes in demography and consequent change in consumer (tourists) taste, education, coupled with globalization, the link between tourism and education is well acknowledged. Globalization has produced modern tourists whose demands surpass that of olden day tourists. Therefore, the curriculum for tourism education must be structured in a manner that it must in addition to other issues address challenges occasioned by globalization.

\subsection{Entrepreneur and Entrepreneurial Education}

Entrepreneurship can be thought as the skill of providing solutions and creating a mechanism aimed at better productivity in different industrial and governmental fields (Aggarua\& Esposito, 2001). That is, 
an entrepreneur is someone who can organize, handle, and undertake calculated risks of an economic activity. Shane and Ulrich, (2001) note that in management sciences, entrepreneurship lays emphasis on 4 factors of decision making, strategy and performance, organizational design, and risk-taking. As suggested by Aisrich and Peters (2005) and supported by literature, the concept of entrepreneurship refers to the future when old and present day's principles and concepts of management change and give way to new conditions. Aisrich and Peters(2005) have gone further to say that entrepreneurship is a process through which something new with almost new values is achieved by spending reasonable time and effort and by taking into consideration the financial and social risks and achieving financial rewards and job satisfaction.

According to Brookes and Altinay (2015), Schumpeter (1934: 354) is known to be one of the early scholars who defined entrepreneurs. Schumpeter defined entrepreneurs as those "individuals whose function is to carry out new combinations of means of production". While entrepreneurship is seen as the process by which individuals carry out this function, it is defined from various perspectives thus, Spencer, Kirchnoff and White (2008) assert there is no universally accepted definition of entrepreneurship. The entrepreneur is seen not only as a person who is capable of bearing risks and starting-up a business but also as an individual who uses his/her skills and personality in order to create value in a company (Gundry, Of stein\&Kickul, 2014).

Entrepreneurship is not limited to creation of new organizations, it can also occur in existing organizations (Shane \& Venkataraman, 2007). Also, it is not only limited to the entrepreneurial individual, but also to entrepreneurial opportunities and the relations between the individual and the opportunity, i.e. the individual-opportunity as described by Shane (2003). Stevenson and Jarillo (1990) define entrepreneurship as "a process by which individuals - either on their own or inside organizations - exploit opportunities without regard to the resources they currently control".

Lundstrom et al (2012) cited The European Council (2006) as describing entrepreneurship as one of the eight key competences that all individuals should have in order to ease business creation and innovation. This view is widely accepted because currently, there is high level of unemployment among young university graduates who have limited opportunity for employment in corporate organizations. Also, these young graduates of present generation do not find paid employment in organizations attractive, they desire achievement, freedom and creativity as key motivators in the workplace, also barriers to entrepreneurship are not difficult to overcome. Most young graduates are always looking forward to either working in big corporate organizations or setting up fast growing industries of their own believing that this offers a better future. Equipped with entrepreneurship skill, someone can have a successful professional life (Daniel, Costa, Pita \& Costa, 2017).

Tourism entrepreneurship has been described as a dynamic factor for developing social life of local communities. As posit by Matthias et al (2019), responsible entrepreneurship is not only about solving economic problems, it can also address social problems such as improving social cohesion and reducing inequalities. It strives to achieve equity, a balance between economic prosperity, social and environmental needs and goals. The foregoing have prompted the tertiary institutions to consider developing tourism education programmes which lay emphasis on teaching and improving individual's entrepreneurial skills while taking cognizance of the fact that new graduates may prefer to become self-employed or innovative employees and enjoy a successful professional life (Daniel et al., 2017), and also become self-reliant.

Education equips entrepreneurs with competencies both non-cognitive and cognitive skills to better analyze, evaluate, detect and exploit entrepreneurial opportunities, increases the level of selfconfidence and reduces perceived risk. Dershuis Van Justion (2003) in Vakili et al. (2016) consider education as one of the major instruments through which entrepreneurship spirit can be cultivated.

A definition of entrepreneurial education has been proposed by Danish Foundation for Entrepreneurship (Moberg, Sternberg \&Vestergaad, 2012, p.14) in Lestari et al (2018) as "Content, methods and activities supporting the creation of knowledge, competencies and experiences that make it possible for students to initiate and participate in entrepreneurial value creating processes". This definition of entrepreneurial education is predicated on the following underlying definition of entrepreneurship: "Entrepreneurship is when you act upon opportunities and ideas and re-create them into value for others. The value that is created can be financial, cultural, or social." (Moberg et al., 2012 , p.14). What is common in the definitions of entrepreneur is the idea of entrepreneurial value 
creation, i.e. that the value created should be novel, but also that it requires some kind of initiative on the part of the individual who is the value creator, that it involves acquisition of resources needed to create the value, that the value creation process is managed and owned by the initiator of the process (i.e. the student) and that this initiator also bears the risk of failure (Shapero\&Sokol, 1982; Okpara \&Halkias, 2011). Entrepreneurially oriented educational programmes in universities have a positive impact on students' entrepreneurial intentions.

\section{REVIEW OF LITERATURE.}

In this section, review of conceptual framework, theoretical foundation and empirical grounds are presented.

\subsection{Conceptual Framework}

Conceptual framework of this review is presented in Figure 2.1. This framework presents competences required of an entrepreneur, entrepreneurial education activities (Curricular and extracurricular) and the expected behavioural outcomes of tourism entrepreneurial education.

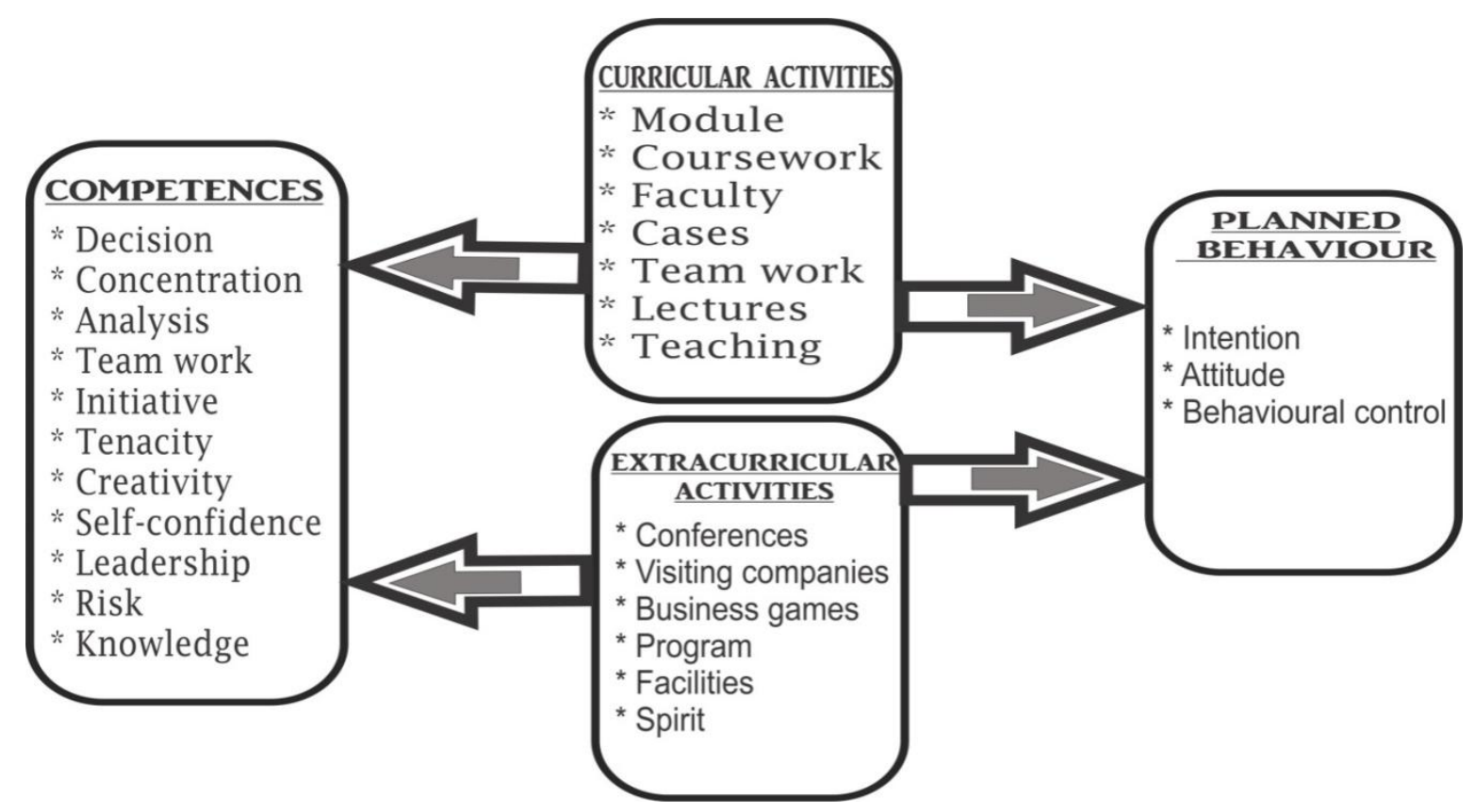

Figure2.1. Conceptual Framework of Tourism Education and Entrepreneurship Vocation.

Source: Arranz, Ubierna, Arroyabe and Perez (2017)

According to Vakili, N. Tahmasebi, S. Tahmasebi and D.Tahmasebi (2016) the application of entrepreneurship education was proposed by Professor Shigeru Fujii of Kobe University, Japan in 1938. In the late 1960s entrepreneurship increased at a remarkable rate. Decades 1980s and 1990, entrepreneurship education witnessed an unprecedented demand. Gourmont (1997) in Vakili et al. (2016) refers to the work done by Bandura who argued that education can be a fundamental principle with regards to establishing or starting a business, through which it is desired that knowledge transfer and acquisition and also development of entrepreneurial skills lead to an improvement in efficiency and effectiveness of the potential entrepreneurs. It is also noted that this fundamental principle can be developed in order to also cover individuals to be prepared for management of small businesses. (Vakili et al., 2016).

Entrepreneurship has played a remarkable role on job creation and economic growth of developed countries which has since been recognized. This has given rise to increasing attempts to educate and teach knowledge and spirit of entrepreneurship to managers, businessmen, and students Vakili et al. (2016). Therefore, organizations, colleges and universities have taken educating and improving human resources as unavoidable responsibilities.

In the opinion of Peter Drucker (1985), the human resource is the rarest resource in any organization (Vakiliet al., (2016). Long-term university educational programmes and short-term practical trainings are among the recommended mechanisms through which human resources, the entrepreneurs' real capitals, and social and cultural capitals can be improved. 
In today's business world most entrepreneurs face the challenge of correctly identifying needs, opportunities, gaps, and more importantly education of real entrepreneurs who need to learn appropriately towards their career life span (Moghimi, Amanpour \&Darayani, 2001). It is on this premise that the concept of continuous learning which is called lifelong learning (L.L.L.) is proposed. According to Khanifer (2006) L.L.L was given much attention by Peter Drucker who stated that "illiterates of the 21 st century are not those who cannot read or write, but they are those who cannot learn or relearn". Currently, the importance of entrepreneurial education is well acknowledged in universities, because it is an opportunity to relearn for some individuals (Charney \&Libecap, 2003).

In Nigeria for example, many universities have incorporated continuing education scheme into their academic programmes which offers businessmen (adults) the opportunity to learn and relearn business management techniques that can help them effectively face present day challenges. It is pertinent to note that entrepreneurship courses form major component of the continuing education curricula. However, the effectiveness of such programmes has not been thoroughly explored through researches.

\subsection{Preparing Entrepreneurs for Hospitality and Tourism Industry}

For entrepreneurial education vocation, a model of education, combining practical hospitality and tourism subjects with industrial training and management lectures whereby students obtain hands-on experience and put their learning to work (Ciochina, Iordache, Sirbu\& Alexandrina, 2016) have become a common practice. For example, in Nigeria, Students Industrial Work Experience (SIWES) has long been incorporated into the curriculum. The industrial training offers the students the opportunity to sharpen their skills. Effectiveness of SIWES depends on the intensity of the training and many other factors. As at the time of this review, there is no evidence that effectiveness of SIWES has been thoroughly investigated.

Daniel et al. (2017) assert that the aim of entrepreneurship education is to empower students with the knowledge of how to launch their own projects, and businesses. The students are taught how to develop their own hospitality/tourism business concepts and enter global competitions with their counterparts. Researchers and scholars see today's world as a change era; which implies that past experiences, techniques and solutions may not be useful for handling currentorganizational issues. Therefore, spirit of entrepreneurship needs to be institutionalized in organizations (Kuratko\& Hodgetts, 2001) and taught in colleges and universities in order to produce entrepreneurs who are able to participate effectively in the global arena.

Through entrepreneurial education, students learn values, abilities and behaviours necessary for facing life's challenges. In recent years, the concept of entrepreneurial knowledge has developed and undergone some changes. Lestari et al. (2012:1) state that entrepreneurship education can shape the psyche, attitude, and behaviour of students into a true entrepreneur thus, guiding them in choosing entrepreneurship as a career choice. Through entrepreneurship learning process, knowledge and skill are imparted in addition to the ability to endeavor and realize personal goals from entrepreneurship itself (Siswadi, 2013) in Lestari et al. (2012).Universities are expected to play crucial role in tourism education, thus, the effectiveness of entrepreneurship education to a great extent depends on how the universities play their role by fostering conducive atmosphere for teaching and learning, Ntshangase \&Ezeuduji (2019). Brown, (2000) in Izedonmi and Okafor (2010:10) opines that entrepreneurial education curriculum should be structured to communicate and inculcate competencies, skills and values needed to identify business opportunities, seize them, organize and start new business ventures.

As indicated by Johnson (1988), Heinonen and Hytti, (2010), O’Connor (2013), entrepreneurial education is often classified into three approaches: Teaching "about" entrepreneurship which means a content-laden and theoretical approach aiming to give a general understanding of the phenomenon. It is the most common approach in higher education institutions (Mwasalwiba, 2010). Teaching "for" entrepreneurship means an occupationally oriented approach aiming at giving potential entrepreneurs the requisite knowledge and skills. Teaching "through" means a process based and often experiential approach where students go through an actual entrepreneurial learning process (Kyrö, 2005).

Entrepreneurs in hospitality and tourism need to possess the keybusiness, technical and managerial skills required to become successful entrepreneurs Ciochina (2016).These operators are responsible for day-to-day running of the businesses, performing management roles of planning, controlling, budgeting, decision-making, organizing, marketing, and management of all aspects of the tourism business, monitor accounting and cash/financial control procedures to ensure that organizational 
goals are achieved. Therefore, the operators need appropriate entrepreneurship education. Morris, Nebb and Singhal (2013) and Sanchez (2013) highlight the importance of developing thinking skills (which enable students to analyze, compare, contrast, criticize and evaluate) and creative skills (with which to imagine or discover) in educational processes.

According to Cooper, Bottomley and Gordon (2004) entrepreneurship education plays three important roles as follows: 1. Strengthening the capacity to generate ideas and innovation, 2. Accelerating business application of these and innovations and extending these capacities, and 3. Creating entrepreneurship education programs which causes those who graduated in the past also become interested in up-to-date and transferable entrepreneurship programmes.

As the controversy on the relationship between higher education institutions and entrepreneurship continues, Linan (2007); Sanchez (2013); Rae (2005), Nabi and Holden (2008); Saarinen and Ursin (20012); and Gibb (2005) are in support of the argument that entrepreneurial education programmes should combine curricular (theoretically and organized education) and extracurricular activities. These authors also express the view that extracurricular activities have positive impact on entrepreneurial vocation. Extracurricular activities include: entrepreneurial experiences in the form of lectures by entrepreneurs, visits to companies and talks on entrepreneurship by outside speakers, learning-bydoing, publication of magazines and materials in general, and other actions that convey the university's vocation and commitment to the values of entrepreneurship.

Collins, Hannon, and Smith (2004); Ertuna and Gurel (2011) and Lestari et al. (2018) have also suggested that universities should play a pivotal role in developing the entrepreneurial vocation of university students. In support of above view, Suharti (2012) in Lestari (2018); Kirby (2004); Maskell and Robinson (2002); Etzkowtz (2004), and Saarinen and Ursin (2012) have suggested the idea of entrepreneurial university in which the pattern of a set of perfectly controlled actions with a systemic approach inculcates entrepreneurial behavior as a culture rather than the exception. Kirby (2005) posits that an entrepreneurial university has the capabilities to innovate, identify and exploit opportunities in the environment, promote teamwork, undertake risks and respond and proffer solutions to challenges.

\subsection{Theoretical Grounds for Tourism Education and Entrepreneurship}

Ajzen (1991); Shapero and Sokol (1982) in (Ajzen, 1991) propose an approach in which intention is considered as the motivational factor that influences behaviour and is considered as the immediate antecedent of behaviour (Kolvereid, 1996; Krueger, 2000), Shapero\& Sokol (1982) in Arranz et al (2017). The formation of an intention is influenced by three antecedents: a favourable or unfavourable evaluation of the behaviour; beliefs concerning the desires of important reference groups to perform or not perform the behaviour; and the perceived ability to perform the behavior (Krueger, 2000).

Scholars and researchers have raised questions of whether the entrepreneurial training programmes given to university students of hospitality and tourism have influenced their activities and imparted the required competence (knowledge, skill and attitude). To answer this question Shapero and Sokol, (1982); and Ajzen, (1991), propose a theoretical model based on the psychological foundations of intentional theory and considering higher education activities as being either "curricular" or "extracurricular". Curricular activities involve participation in formal learning scheme involving the teaching of skills and attitudes, while extracurricular activities include support for cognitive, informative/formative and instrumental activities (See Figure 2.1 above). Similarly, Sanchez (2013) analyzed the results of courses for entrepreneurs and reported that the development of educational programmes has an impact on skills for entrepreneurship such as risk-taking, self-efficacy, and proactiveness.

The structure of education in tourism and hospitality has a multidisciplinary nature, and it combines vocational education with business and management skills (Tribe, 2000b; Airey \& Tribe; 2005; Fidgeon, 2010; Solvoll, Alsos, \&Bulanova (2015). Most of the works done by higher education institutions to develop entrepreneurial vocation adopted a psychological approach (Theory of Planned Behaviour, See Fig. 1, Azjen, 1991), and involve encouraging the intentions, attitudes and behavioural control of university students (Boissin, Branchet, Emin\& Herbert (2009); Autio, Keeley, Klofsten\&Ulfstedt, 1997). The cognitive psychological approach offers a useful viewpoint to analyze the phenomenon of entrepreneurial decision through the study of perceptions and intentions. 
Scholars and researchers have provided differing answers to the question as to whether the entrepreneurial training programmes given to university students of hospitality and tourism have influenced their activities and imparted the required competencies (knowledge, skill and attitude), (Shapero\& Sokol, 1982; Ajazen, 1991). While some researchers say that entrepreneurial education has no and/or negative impact on the students, others say that the training has positive impact (Sanchez, 2013). In our contribution to the debate, we lend our support to the Theory of Planned Behaviour and to the view that entrepreneurial training has positive impact on the students. Our view leans on a socio-psychological theory- Expectancy Theory of Motivation by Vroom (1964) in Igbojekwe and Agbonye (2009).Generally, theories of motivation explain what energizes, directs, and sustains a person's efforts (behaviours). The Expectancy theory of Motivation (ETM) explains how and what offered, and antecedents preceding the offer influence individual's behavior. The underlying bases of this theory are that individual's behavior is influenced by expected results of their actions and that people are motivated by the value (valence) and desirability of the expected outcome. The theory goes further to emphasize that there should be a link between effort and performance (outcome) and a link between performance and reward (instrumentality). From the perspective of ETM we attempt to make explanation to the phenomenon of entrepreneurial education and its impact on students. The intention of the training is to prepare them to acquire the necessary competencies to become successful entrepreneurs after they graduate from the university which is their desirable aspiration and the intended reward of the tourism entrepreneurial education. Young university graduates aspire to become successful professionals, self-employed and self-reliant or on the alternative work for a fastgrowing business organization. They would be motivated to acquire entrepreneurial education through which they build self-confidence, and by the perceived achievements and benefits derivable from being tourism entrepreneurs.

\subsection{Empirical Ground}

Researchers have conducted studies on the relationship between tourism entrepreneurial education and its influence on entrepreneurship spirit. However, most of the studies explored the effectiveness of the activities to promote entrepreneurial vocation (for example, Autio et al. 1997);Boissin et al. (2009); and Elmuti and Khoury (2012)and concluded that the incorporation of subjects related to entrepreneurship in the syllabus appears to facilitate the tendency to choose entrepreneurship by the participants. A research work by Arranz et al. (2017), and Elmuti and Khoury (2012) with university students, revealed that participation in subjects involving the creation of companies indicated positive inclination to participants' entrepreneurial intention.

According to Liñan and Chen, 2009; Boissin et al. 2009; Sanchez, 2013) previous studies have confirmed that university education has a positive effect on the acquisition of prerequisite skills and competences for developing entrepreneurial spirit. Garavan and O'Cinneide (1994) have reported that education can influence entrepreneurship in a positive or negative way. Peterman and Kennedy (2003) also note that "formal education does not necessarily encourage entrepreneurial vocation, but instead leads to conformity and a reduces tolerance for ambiguity, decreases students' capacity for creative thinking and inhibiting their creativity and entrepreneurial spirit". Laukkanen (2000) emphasizes that higher education institutions not only make their students too analytical, overly conscious of problems and risk-averse, but also scare their students off starting new business ventures. Grebel et al, (2003) in Arranz et al (2017) and Ertuna and Gurel (2011) have noted the debate arising from the teaching of entrepreneurial vocation as a subject. Arranz et al. (2017) and Ajazen (1991) suggest that entrepreneurial training should aim at improving the feasibility and desirability of creating a business.

Laukkanen (2000) suggests the creation of an educational system based fundamentally on process of teaching entrepreneurship in education. Laukkanen (2000) notes that the teacher's pedagogy has influence on the outcome of the educational system, therefore, teacher's pedagogy has been recognized as a crucial component for consideration in developing entrepreneurial skills and aptitudes.

Some researchers such as Laukkanen, (2000); Morris et al., (2013); and Sanchez, (2013) have also looked at higher education from certain dimensions. Their works explored the influence of curricular and extracurricular activities on entrepreneurial competencies. Morris et al. (2013, p. 353) define competency as follows: "Competency refers to the knowledge, skills, attitudes, values, and behaviours that people need to successfully perform an activity". Sanchez (2013), Rasmussen et al. (2011) and Morris et al. (2013) classified entrepreneurial competencies into those of psychology (self-efficacy, 
proactiveness, and risk-taking), relations and management (leadership and teamwork), and knowledge competencies.

Arranz et al. (2017) also concluded from their study that curricular activities have some effect on the entrepreneurial competencies of tourism students. Elmuti and Khoury (2012) concluded from their own study that there is a causal linkage between entrepreneurial education and ventures' effectiveness. In summary, these researchers concluded that both curricular and extracurricular activities have positive influence on the cultivation of entrepreneurial competencies. In general terms, competencies are developed based on class content, the faculty and teamwork. Arranz et al. (2017) claim that curricular activities facilitate development of interactive competencies such as leadership and teamwork; and to lesser extent psychological competencies such as self-efficacy, proactiveness and risk-taking (Laukkanen, 2000; Sanchez, 2013).

A research conducted by Lestari et al (2018) with students of TheTrisakti School of Tourism showed that their students got inspired when exposed to entrepreneurial subjects. Entrepreneurial subjects changed their point of view, attitudes, behaviors and perception. The result of their study showed positive and linear relationship between entrepreneurship education and entrepreneurship interest in the students of Trisakti School of Tourism; and the relationship was found to be moderate and entrepreneurship spirit was influenced by entrepreneurship subject. These findings suggest that students will be interested to start their own businesses after they graduate from college.

Ntshangase and Ezeduji (2019) concluded from their study that entrepreneurial education prepares students' interest in taking risk as business owner, training programmes are very important and should be provided to low-skilled tourism entrepreneurs for long-term survival of their businesses and that entrepreneurial success depends on educational level.

ELmuti and Khoury (2012) reported findings from their study which indicated that there is causal link between entrepreneurial training skills and ventures' effectiveness; entrepreneurial education and training programmes appear to create confidence and trust among the participants in their study.

\section{Summary/Conclusion}

Hospitality and tourism sectors have become a major force driving socio-economic development in many countries of the world. Tourism and hospitality are inter-related and interdependent. Tourism is multidisciplinary and dynamic. It is a growth industry and very competitive. It constantly undergoes changes, therefore, there is the need to educate/train both practitioners and students in order to equip them with the appropriate competencies to help them become successful entrepreneurs. Tourism entrepreneurship is widely acknowledged as a mechanism for creating jobs, solving unemployment problems in both developed and emerging economies (such as Nigeria). Entrepreneurs identify opportunities, exploit them, create employment for themselves as well as for others. Tourism as a sector has some unique features, thus, requires industry specific training/ education to produce successful entrepreneurs.

As proposed by researchers, tourism education should adopt vocationally oriented approach by combing curricula and extracurricular activities and that universities should play pivotal role in this regard. There is an ongoing debate as to whether tourism education offered by universities and colleges have produced entrepreneurs. In this context, there are mixed results and opposing views. Some scholars say that tourism education has negative impact, while others say that it has positive impact on students. As revealed in the literature, there are conceptual and theoretical grounds and ample empirical evidence supporting the view that there is positive relationship between tourism (and hospitality) education offered by universities and colleges and entrepreneurship development.

It has been observed that there is high level of youth unemployment in most countries; this is the reason why it has become inevitable to inculcate entrepreneurship spirit in students so that they will become entrepreneurs when they graduate from the university. Also observed is that the present-day youths do not find paid employment attractive, hence, they look forward to setting up their own businesses. In this context, entrepreneurial education becomes an imperative. It is suggested that the need for achievement, self-employment, self-reliance and expected benefits of entrepreneurship are the motivating factors enhancing cultivation of entrepreneurship spirit among the youths. An expanding hospitality and tourism industry can offer them great opportunity to actualize their aspirations. 


\subsection{Recommendation}

As observed earlier, there are no research evidence confirming the appropriateness and effectiveness of entrepreneurial education offered by Nigerian colleges and universities, hence, we recommend that such researches be conducted. We recommend that collaboration between the industry and higher education institutions is inevitable for cultivating the relevant entrepreneurial competencies in students particularly in an emerging economy such as Nigeria.

\section{REFERENCES}

[1] Aggarul, R., \&Eposito, M. (2001). The technology Entrepreneur's Guide Book. Nasday India. CEO HyTechGoucil, U.S Chamber of Commerce, D.C. USA.

[2] Airey. D. \& Johnson, S. (1999). The content of tourism degree courses in the U.K. Tourism Management, 20. 229-235.

[3] Airey, D. \& Tribe, J. (2005). An International Handbook on Tourism Education. Oxford: Elsevier.

[4] Ajazen, I. (1991). The theory of human behavior. Organizational Behaviour and Human Decision Process, 50, 179-211.

[5] Arranz, N., Ubierna, F., Arroyabe, M. F., \& Perez, C. (2019). The effect of tourism education on students' entrepreneurial vocation. Scandinavian Journal of Hospitality and Tourism, 17(3).

[6] Autio, E., Keeley, R. H., Klofsten, M., \&Ulfstedt, T. (1997). Entrepreneurial intent among students testing an intent model in Asia, Scandinavia, and USA. Frontiers of Entrepreneurship Research, Boston Conference Proceedings, Boston, MA.

[7] Bossin, J. P., Branchet, B., Emin, S., \& Herbert, J. (2009b). Students and entrepreneurship: A comparative study France - United States. Journal of Small Business and Entrepreneurship, 22(2), 101-122.

[8] Brookes, M. \&Altinay, L. (2015). Entrepreneurship in hospitality and tourism: A global Perspective. Goodfellow Publishers Ltd. Retrieved 04/05/2020 from http://www.goodfellowpublishers.com

[9] Busby, G., \& Huang, R. (2017). Integration, intermediation and tourism higher education: conceptual understanding in the curriculum. Tourism Management, 33, 108-115

[10] Charney, A. H. \&Libecap, G.D. 2003) The contribution of entrepreneurship education: an analysis of the Berger Program. International journal of Entrepreneurship 1, 385-417

[11] Ciochina, J. Iordache, C.M., \&Sirbu Alexandrina (2016). Entrepreneurship in the tourism and hospitality industry.

[12] Collins, L. Hannon, B. D., \& Smith, A. (2004). Enacting entrepreneurial intent: the gaps between student needs and higher education. Education + Training 46 (8), 349-372

[13] Cooper, S., Bottomley, C, \& and Gordon (2004). Stepping out of the classroom and up the ladder of learning: an experiential learning approach to entrepreneurship education. Industry and Higher Education, $18,11-22$

[14] Daniel, A., Costa, R., Pita, M. \& Costa, C. (2017). Tourism education: What about entrepreneurial skills. Journal of Hospitality and Tourism Management, 30, 65-77

[15] Echtner, C. M. (1995). Entrepreneurial training in developing countries. Annals of Tourism Research, 22)1), 119-134

[16] Elmuti, D. \& Khoury. G. (2012). Does entrepreneurship education have a role in developing entrepreneurial skills and ventures' effectiveness. Journal of Entrepreneurship Education 15, 83-98

[17] Ertuna, Z. \&Gurel, E. (2011). The moderating role of higher education on entrepreneurship. Education + Training 53(5), 387-402.

[18] Fidgeon, P. (2010). Tourism education and curriculum design: a time for consolidation and review? Tourism Management, 31(6), 699-723

[19] Garavan, T. N. \&O'Cinneide,B. (1994). Entrepreneurship education and training programs: a review and evaluation, part 1. Journal of entrepreneurial Training 18, 3-12.

[20] Gibb, (2008). Entrepreneurship and enterprise education in schools and colleges: insight from UK, practice. International Journal of Entrepreneurship Education, 6, 48

[21] Gundry, L.K., Ofstein, L. F., \&Kickul, J. (2014). Seeing around corners: How creativity skill in entrepreneurship education influence innovation in business. The International journal of Management Education, 12(3).

[22] Jafari, J. (2000). Encyclopedia of Tourism. Retrieved 5/5/2020 from www.springer.com

[23] Johnson, C. (1988). Enterprise education and training. British journal of Education and Work, 2.61-65

[24] Igbojekwe, P. A. \&Agbonye, O. C. (2009). Expectancy theory of motivation and appraisal of and its relevance in solving motivation problem of the Nigerian worker. Journal of Business Communication Technology, Volume 1(2), 78-91 
[25] Izedonmi, P.F. \& Okafor, C. (2010). The effect of entrepreneurship education on students' entrepreneurial intentions. Global Journal of Management and business Research, 10(6), 49-60

[26] Khanifer, H. (2006). Entrepreneurship in Education System. Qom, Ekram Publication.

[27] Kirby, D.A. (2004). Entrepreneurship education: can business schools meet the challenge? Education + Training, 46, 510-519.

[28] Koh, K. (1995). Designing the four-year tourism management curriculum: a marketing approach. Journal of travel Research, 33(1), 68-72.

[29] Kolveried, L. 1996). Prediction of employment status choice intentions. Entrepreneurship Theory and Practice 12(1), 25-47.

[30] Krueger, N. F. (2000). Entrepreneurial intentions are dead: long live entrepreneurial intentions, understanding the entrepreneurial mind. Springer.

[31] Kuratko, D. F., \& Hodgetts, R. M. (2001). Entrepreneurship: A contemporary Approach. N.Y. Harcount College Publisher,

[32] Kyro, P. (2005). A theoretical framework for teaching and learning entrepreneurship. International journal of Business and Globalization, 2, 39-55.

[33] Laukkanen, M. (2000). Exploring alternative approach in higher-level entrepreneurship education: creating micro-mechanisms for endogenous regional growth. Entrepreneurship and Regional Development 12(1), $25-47$

[34] Lestari, N., Novita W., \&Festtivalia, F. (2018). Effect on entrepreneurship subject towards entrepreneurship interest for tourism higher education students. Advances in Economics, Business and Management, Vol. 52.

[35] Li, L. (2008). A review of entrepreneurship research published in the hospitality and tourism management journals. Tourism Management 29, 1013-1022.

[36] Linan, F. \& Chen, Y. 2009). Development and cross-cultural application of a specific instrument to measure entrepreneurial intentions. Entrepreneurship Theory and Practice, 33, 593-617.

[37] Lundstrom, A. \& Stevenson, L. (2012). Theories of entrepreneurship, innovation and the business cycle. Retrieved 5/5/2020 from onlinelibrary.wiley.com

[38] Maskell, D. \& Robinson, I. (2002). The New Idea of a University. Thorverton, U.K. Retrieved 4/4/2020 from: www.amazon.com

[39] Mathieson, A.\&Walls, G. (2006). Tourism, Impacts, and Opportunities. Harlow: London, Pearson Prentice Hall.

[40] Matthias, F., Sascha, K., Norat, R.T., Norbert, K. \& Ulrike, F. (2019). Entrepreneurship as catalyst for sustainable development: Opening the black box.

[41] Meyer, D. F. \& Meyer, N. (2015). The role and impact of tourism on local economic development: A comparative study. African Journal for Physical Health education, Recreation and Dance, 21(1), 197-214

[42] Momberg, K., Stenberg, E., Vestergaad, L. (2012). Impact of entrepreneurship education in Denmark. Odense, Denmark. The Dannish Foundation for Entrepreneurship-Young Enterprise.

[43] Morris, M., Webb, J., Fu, J. \& Singhal, S. (2013). A competency-based perspective on entrepreneurship education: A conceptual and empirical insights. Journal of Small Business Management, 51(3), 352-369.

[44] Mwasalwiba, E, S. (2010). Entrepreneurship education: A review of its objectives, teaching methods and impact implication. Education + Training, 52, 20-47

[45] Nabi, G. \& Holden R. (2008). Graduate entrepreneurship: Intentions, education and training. Education + Training, 50(7), 545-451.

[46] Ntshangase, S. D. \&Ezeuduji, I. O. (2019). The attributes of successful tourism-related entrepreneurs: A case from South Africa. EuroEconomica, Volume 38(2).

[47] O'Connor, A. (2013). A conceptual framework for entrepreneurship education policy: Meeting government and economic purposes. Journal of Business Venturing, 28, 546-563

[48] Okpara, J. O. \&Halkias, D. (2011). Social entrepreneurship: An overview of its theoretical evolution and proposed research model. International Journal of Social Entrepreneurship and Innovation 1, 2-0.

[49] Peterman, N.E. \& Kennedy, J. (2003). Enterprise education: Influencing students' perception of Entrepreneurship. Entrepreneurship Theory and Practice 28 (2), 129-141

[50] Rae, D. (2010). Universities and enterprise education: Responding to the challenges of the new era. Journal of Small Business and Enterprise Development, 17, 591-606.

[51] Rasmussen, E. A. \&Sorkein, R. (2000). Action-based entrepreneurship education. Technovation, 26, 185194

[52] Reisinger, Y. (2009). International Tourism: Cultural and Behavior. Burlington, M. A. Elsevier Publisher

International Journal of Research in Tourism and Hospitality (IJRTH) Page| 10 
[53] Rusu, S., Isac, F., \&Cureteanu, R. (2016). Worldwide tourism entrepreneurship: A global perspective. Facultatea de Management Agricolanagement Agricol, 17(4), 64-68.

[54] Saarinen, T., \& Ursin, J. (2012). Dominant and emerging approaches in the study of higher education policy change. Studies in Higher Education, 37(2), 143-156.

[55] Sanchez, J. C. (2013). The impact of entrepreneurship education program on entrepreneurial competencies and intention. Journal of small Business Management, 5(3), 447-465.i,

[56] Saner, T., Bahceleri, N. M. \&Eyupogl, S. Z. (2019). Importance of practical in tourism.

[57] Schumpeter, T. (1934). The Theory of Economic Development: An Inquiry into Profits, Capital, Credit, Interest, And the Business Cycle. Cambridge, Harvard university Press.

[58] Shapero, A., \& Sokol, L. (1982). The social dimension of entrepreneurship in Arranz et al. (2019). The effect of tourism education on students' Entrepreneurial vocation. Scandinavian Journal of Hospitality and Tourism, 17(3).

[59] Shane, S. A. (2003). A General Theory of Entrepreneurship: The Individual-Opportunity Nexus. Edward Elgar Publishing.

[60] Shane, S, \&Venkataramau, S. (2000). The promise of entrepreneurship as a field of research. Academy of Management Review, 25(1), 217-226.

[61] Spencer, S., Kirchnoff, B., \& White, C. (2008). Entrepreneurship, innovation and wealth distribution. International small business Journal 26(1), 9-26.

[62] Solvoll, S., Alsos, G. A. \&Bulanova, O. (2015). Tourism entrepreneurship - Review and future directions. Scandinavian Journal of Hospitality and Tourism, 15(1), 120-137.

[63] Stevenson, H. H. \&Jarillo, J. C. (1990). A paradigm of entrepreneurship and entrepreneurial management. Strategic Management Journal, 11, 11-27.

[64] Tribe, J. (1997). The indiscipline of tourism. Annals of Tourism Research, 24, 638-657.

[65] Ugo-Okoro, C., Igbojekwe, P. A. \& Ogbonna, C. (2011). Hospitality and tourism education in colleges and universities in Nigeria: Challenges and prospects, HATMAN Journal of Hospitality and Tourism, Vol. 1(1), 74-79.

[66] United Nations World Tourism Organization [UNWTO] (2015). Tourism and the sustainable development goals. Madrid. UNWTO. Retrieved 4/5/2020, from htt://www.eunwto.org

[67] Vakili, F., Tahmasebi, N., Tahmasebi, S. \& Tahmasebi, D. (2016). Role of education in entrepreneurship development. Journal of EcophysiolOccp. Health 16(3), 78-87

Citation: Polycarp A. Igbojekwe, Omelebele U. Anuñobi. "Hospitality and Tourism Education and Making of Entreprenuers: A Review ". International Journal of Research in Tourism and Hospitality (IJRTH), vol 6, no. 3, 2020, pp. 01-11. doi: https://doi.org/10.20431/2455-0043.0603001.

Copyright: () 2020 Authors. This is an open-access article distributed under the terms of the Creative Commons Attribution License, which permits unrestricted use, distribution, and reproduction in any medium, provided the original author and source are credited. 